\title{
Programlama Eğitiminde Scratch’in Kullanılması: Öğretmen Adaylarının Tutum ve Algıları
}

\section{Using Scratch in Programming Language: Teacher Candidates' Attitudes and Perceptions}

\author{
Kürşat Arslan ${ }^{1}$ \\ Melike Akçelik ${ }^{2}$
}

Alıntılama: Arslan, K. \& Akçelik, M. (2019). Programlama eğitiminde Scratch'in kullanılması: Öğretmen adaylarının tutum ve algıları. Ulusal Eğitim Akademisi Dergisi (UEAD), 3(1), 41-61.

Geliş tarihi:

28 Ağustos 2018

Kabul tarihi:

29 Mart 2019

(C) UEAD 2019

Tüm hakları saklıdır.

Received:

28 August 2018
Özet: $\mathrm{Bu}$ çalışma, genellikle küçük yaş gruplarında tercih edilen Scratch programının, yüksek öğretimde programlama eğitiminde kullanılmasına yönelik Bilgisayar ve Öğretim Teknolojileri Eğitimi Bölümü bölümü 1. sınıf öğrencilerinin algılarının incelenmesi ve Scratch uygulamasından önce ve sonra öğrencilerin tutumlarının değerlendirilmesi içerir. Araştırma, 2016-2017 öğretim yılı bahar döneminde Dokuz Eylül Üniversitesi, Eğitim Fakültesi, Bilgisayar ve Öğretim Teknolojileri Eğitimi Bölümünde 1. sınıfta öğretim gören 32 öğretmen adayı ile karma araştırma deseni kullanılarak yapılmıştır. Veriler; tutum ve öz yeterlilik ölçeklerine dayanan nicel ve yarı yapılandırılmış birebir görüşmelerden oluşan nitel verilerden oluşmaktadır. Araştırma sonucunda, genel olarak eğitimden önce öğrencilerin programlamaya ilişkin algılarının pozitif olduğu ve Scratch kullanımından sonra bu algının olumlu yönde daha da arttığı gözlenmiştir. Araştırmanın nitel bulgularında ise katılımcılar için Scratch eğlenceli, oyunlaştıran, sonuçların hemen görüldüğü, kolay, görsel ve Türkçe bir programlama aracı olarak algılandığı görülmüştür. Bununla birlikte, bu yazılımın üniversite düzeyinde bir programlama dili olarak değil de, programlama eğitiminden önce bir başlangıç aracı olarak kullanılması gerektiği araştırma sonucu ortaya çıkan bir diğer bulgudur. Ayrıca sonuçlar, Scratch'in öğretmen adaylarının gelecekteki öğrencileri için kullanılmasının hem gelişen teknolojiler hem de onların artan talepleri doğrultusunda zorunlu olduğunu göstermiștir.

Anahtar kelimeler: Scratch, programlama öğretimi, tutum, alg1.

Abstract: This study includes the examination of the perceptions of first-year students in the Department of Computer Education and Instructional Technology for the use of Scratch program, which is generally preferred in small age groups, in programming education, and evaluation of the students' attitudes before and after the Scratch application. The research was carried out by using mixed method design in

\footnotetext{
${ }^{1}$ Dr. Ögrr. Üyesi, Dokuz Eylül Üniversitesi, kursata@gmail.com, ORCID ID: 0000-0003-4680-9561.

${ }^{2}$ Melike Akçelik, Dokuz Eylül Üniversitesi, makcelik123@gmail.com.
} 


\begin{abstract}
Accepted:
29 March 2019

(C) UEAD 2019

All rights reserved.

the spring semester of 2016-2017 academic year with 32 pre-service teachers in the Department of Computer Education and Instructional Technology at Dokuz Eylül University. Data includes quantitative data including attitude and self-efficacy scales and qualitative data including semi-structured face-to-face interviews. The results of the study showed that students' perceptions about programming were positive before the training in general and that this perception increased more after the use of Scratch. In the qualitative findings of the study, it was seen that Scratch was perceived as an easy, visual and Turkish programming tool, which was fun, playful, and physical programming language. In addition to this, another result of the study is that according to students this software should be used as a starting tool before programming courses, rather than as a university level programming language. In addition, the results showed that the use of the Scratch software for future students of prospective teachers is mandatory for both emerging technologies and their increasing demands.
\end{abstract}

Keywords: Scratch, programming language, attitude, perceptions.

\section{Giriş}

Günümüzde programlama, artık bütün öğrencilerin kazanması beklenen "21. Yüzyıl becerisi” olarak kabul edilmektedir. Buna bağlı olarak, ülkeler özellikle ilk ve orta öğretim programlarına kodlama becerilerini geliştirecek farklı derslerin ya da uygulamaların entegre olmasını sağlamışlardır. Yapılan çalışmalara bakıldığında, Avrupa ve Amerika'da ve son zamanlarda da Türkiye'de özellikle küçük yaş gruplarında programlama öğretimini desteklemek için dersler eşliğinde çeşitli çalışmalar, etkinlikler ve uygulamaların yapılmakta olduğu görülmektedir (Resnick ve Diğ., 2009; Kordaki, 2012; Karabak ve Güneş, 2013; Kobsiripat; 2015). Nitekim Millî Eğitim Bakanlığı, kodlama eğitimine daha fazla vurgu yapmak için 2013 yılı sonlarında Bilişim Teknolojileri dersinin adını "Bilişsim Teknolojileri ve Yazılım” olarak değiştirmiş ve seçmeli olan dersi zorunlu hale getirmiştir. Bu değişikliğin temelinde yaşadığımız çağda yetişen bireylerde bulunması gereken yaratıcılık, analitik düşünme, problem çözme ile özgün ürün geliştirme gibi bilişsel ve piskomotor becerilerin küçük yaşta öğrencilere kazandırılmasının gerekliliği yatmaktadır (Shin, Park ve Bae, 2013; Karabak ve Güneş, 2013). Bu ders, 5. sınıftan başlamak üzere 8. sınıfa kadar kodlama eğitimini destekleyen çeşitli konu başlıklarını içermektedir. Örneğin, "Problem Çözme", "Programlama" ve "Özgün Ürün Geliştirme” söz konusu konu başlıkları arasında sadece birkaçıdır. Ayrıca, Türkiye Bilimsel ve Teknolojik Araştırma Kurumu (TÜBİTAK) tarafından desteklenen birçok proje, özellikle genç öğrencilerin kodlama becerilerini geliştirmeyi amaçlamaktadır. Örneğin, TÜBİTAK tarafından "Bilişim teknolojileri Öğretmen adaylarına yönelik bilgisayar programlama öğretiminde alternatif yöntem ve araçlar semineri” adlı projeyle farklı tarihler arasında çeşitli etkinlikler yoluyla öğretmen adaylarına programlama 
konusunda güncel bilgi ve uygulamaların tanıtılması ve öğretmen adaylarının bu konuda desteklenmesi amaçlanmıştır.

Programlama dili, "elektronik cihazların yani donanımların belirlenen amaçlara hizmet edebilmeleri için kullanılan özel kelime ve sembollerden oluşan komutlar bütünü yani yazılımlar” olarak tanımlanabilir (Arslan ve Tanel, 2017, p.665). Yazılan komutların belli bir işi yapması bir bilgisayar ya da doğrudan bir mikro işlemciyle yapılması sağlanır. Her programlama dili kendine özgü bir syntax (yazıl dili) ve komut diline sahiptir. Ve bu dile özgün komutların, herhangi bir işlemi yapmak için yazılmasına kodlama, bunun online ya da masaüstü bir uygulama olarak son kullanıcıya ulaşmışş şekline ise program denir (Arslan ve Tanel, 2017). Bir programlama dilinin öğretilmesi ise belirli basamaklardan oluşmaktadır. Bunlar;

1. Algoritma ve akış diyagramı gibi temel konular,

2. Programlama diline ait kavramlar,

3. Program yazarken kullanılan yabancı dil olarak öngörülmektedir.

Programlama eğitiminin öğrencilere, yaratıcılık, sistematik düşünme ve problem çözme konularında katkı sunduğu bir çok çalışma tarafından ortaya konulsa da, programlama dillerinin ağır kavramsal yapısının özellikle yeni başlayan öğrenciler ya da öğretmen adayları için oldukça zorlayıcı olduğu vurgulanmaktadır (Cetin, 2016; Rubio ve diğerleri, 2013; Jenkins, 2002; Allan ve Kolesar, 1997). Programlama dilinin söz dizimi, kavramların soyutluğu, karmaşık kullanıcı arayüzü ve yabancı dil kullanılması da programlama öğrenmede karşılaşılan diğer zorluklardır. Genellikle eğitim programlarında, programlamaya başlarken, kullanımı öğrenci açısından zor olan $\mathrm{C}$ ve Pascal gibi temel programlama dilleri öğretilerek başlanılır. Bu diller hem yapıları hem de sahip oldukları yetenekler bakımından güçlü olmalarına karşın, ağır yazım kuralları içerdiği ve göreceli olarak orta seviye programlama dilleri olduğundan öğrencilerin çoğu temel adımları anlayamadığı ve zamanla yapabilirliklerinin azaldığı görülmektedir. $\mathrm{Bu}$ durumun öğrencilerin motivasyonlarını oldukça olumsuz etkilediği (Robins ve diğerleri, 2003) ve programlamaya karşı bir öz-yeterlilik eksikliği oluşturduğu tespit edilmiştir (Davidson ve diğerleri, 2010; Mazman ve Altun, 2013). Programlama öğretiminde sıralanan sorunların yaşanmasının bir sonucu olarak, Scratch'in de içinde bulunduğu çeşitli yazılımlar geliştirilmiş ve görsel programlama, tasarımla öğrenme ve oyunla öğrenme gibi kavramlar ve araştırma konuları ortaya çıkmıştır (Maloney ve diğerleri, 2008). Bu çalışma için Scratch 'in seçilmesinin temel nedenleri, günden güne artan bir 
kullanıcı kitlesine sahip olması, program arayüzü ve kodlamada Türkçe dil seçeneğinin olması ve yeni kullanıcılar için oldukça basit bir arayüz sağlaması olarak sıralanabilir.

Scratch, 2003 ile 2007 yılları arasında MIT (Massachusetts Teknoloi Enstitüsü) Medya Labaratuvarı tarafından geliştirilen, Amerikan Ulusal Bilim Kurumu tarafından desteklenen bir proje olarak ortaya çıkmıştır. Projenin temel amacı, özellikle okul dışı faaliyetlerde ve görece olarak sınırlı imkanlara sahip bölgelerde küçük yaş grupları için teknoloji kullanma becerilerini ve okuryazarlıklarını basit kodlama teknikleri ile artırmaktır (Resnick ve diğerleri, 2003). Scratch, görsel arayüz ile sürükle-bırak yöntemi kullanılarak uygulama, oyun, animasyon geliştirilebilen; içerdiği eğitim ve rehberliklerle kullanımının bireysel olarak öğrenilebildiği, yardım alabileceğiniz komünitesi bulunan bir platformdur. Sahip olduğu özellikler ile öğrencileri ürünü geliştirme sürecinin zorluğundan kurtararak tüm enerji ve dikkatlerini hayal ettikleri ürünü daha iyi hale getirmeye odaklamalarına olanak sağlamaktadır. Scratch ortamında program yazımı, kodların bir yerden bir yere sürüklenip bırakılmasıyla gerçekleşmektedir. Birbirleriyle ilişkili olmayan bir kod diğer kod ile birleşmemektedir. Bu özellik sayesinde, programlamada en büyük sorunlardan biri olan söz dizimi hataları ortadan kaldırılmış ve komut ezberlemeye gerek kalmamıştır (İsmail ve diğerleri, 2010; Karabak ve Güneş, 2013; Maloney ve diğerleri, 2004).

Scratch ve benzeri uygulamalarla programlama bilgi ve becerilerini artırma, alanyazında görsel programlama olarak etiketlenmiştir. Bunun temel nedeni, programlamanın kod yazımı ile değil de görsel araçların sürükle ve bırak yöntemi kullanılarak yapılmasıdır. Böylece, programlama konusunda deneyimi olmayanlar ya da çocuklar için kod yazım hatalarına düşmeden, basit bir arayüz kullanarak kolaylıkla tasarlama ve üretme imkânı sunmaktadır. Özellikle programlama eğitimini erken yaşta alan çocuklarda, görsel programlamanın kullanılması farklı düşünme, yaratıcılık ve yönlendirme gibi üstbiliş yeteneklerinin gelişmesine (Akpınar ve Altun, 2014; Atmatzidou ve Demetriadis, 2016) ve ayrıca programlamaya yönelik algı ve tutumlarının olumlu yönde artmasına katkı sağladığı görülmüştür (Fessakis ve diğerleri, 2013; Günüç ve diğerleri, 2013). Bununla beraber matematik ve bununla ilişkili konuların öğretiminde programlama eğitiminin öğrenciler üzerinde pozitif etkileri olduğu belirlenmiştir (Taylor, Harlow ve Forret, 2010). Yakın zamanda yapılan bir diğer çalışmada, küçük yaş gruplarında Scratch programının kullanılması öğrencilerin yaratıcılık ve girişkenlik becerileri üzerinde olumlu ve anlamlı bir etkiye sahip olduğu gösterilmiştir (Kobsiripat, 2015). 
Yükseköğretim düzeyinde programlama dilleri öğretiminde kullanılan yöntemler, bu yöntemlerin etkililiği, öğrencilerin bu derslere yönelik tutumu ve başarısı konusunda alanyazında yukarıda da sıralandığı gibi yeterince çalışma bulunmakta ve bu çalışmalar sonucu yeni bir yöntemin ya da yaklaşımın denenmesi gerektiği vurgulanmaktadır. Buna ek olarak Ülkemizde güncellenen Bilişim Teknolojileri ve Yazılım dersinin kazanımları programlama becerilerinin geliştirilmesine yönelik hedefler de içermektedir. Dolayısyla yükseköğretimde programlama dilleri dersi içinde bu kazanımlara yönelik bir uygulamanın denenmesi ve sonuçlarının analiz edilmesi faydalı olabilir.

Programlama eğitiminde karşılaşılan ve yukarıda detaylarıyla sıralanan problemler 1şığında, yüksek öğretimde öğretmen adaylarının, ileri seviye programlama dili eğitimi görmeden önce Scratch gibi küçük yaş grupları ve yeni başlayanlar için geliştirilen bir uygulamanın kullanılması, onların programlamaya dönük olumsuz tutum ve davranışlarını değiştirebilir ve başarılarını olumlu yönde etkileyebilir.

Sonuç olarak, bu çalışmanın amacı, programlama eğitiminde yukarıda sıralanan çeşitli sorunlara, görsel programlama araçlarından biri olnan Scratch programı kullanılarak, bu programa ilişkin öğrencilerin alg1 ve beklentilerini, onlara programlama eğitiminde ne gibi katkılar sunacağını ortaya çıkarmak ve bir çözüm önerisi sunmaktır. Bu amaç doğrultusunda, Dokuz Eylül Üniversitesi Buca Eğitim Fakültesi, Bilgisayar ve Öğretim Teknolojileri Eğitimi (BÖTE) bölümü 1. sınıf öğrencilerine 3 hafta süren Scratch eğitimi verilmiş ve programaya ilişkin görüş ve algıları ölçülmüştür. Ve elde edilen veriler ışığında aşağıdaki araştırma sorularına yanıt bulunmaya çalışılmıştır.

1. Öğrencilerin programlamaya ilişkin öz-yeterlilikleri ne düzeydedir?

2. Öğrencilerin Scratch programına ilişkin algıları nasıldır?

3. Öğrencilerin, 3 haftalık Scratch eğitiminden sonra algılarında nasıl bir değişim meydana gelmiştir?

\section{Yöntem}

Greene, Krayder ve Mayer'e göre (2005) sosyal bilimlerde iki ya da daha fazla yöntem veya veri toplama tekniği bir arada kullanıldığında, karma yöntem yaklaşımı kullanılmış olmaktadır. Alanyazında bu tip araştırmaların kullanılması oldukça yaygındır (Verma ve Mallick, 2005). Araştırmada nitel ve nicel tekniklerin bir arada kullanıldığı karma yöntem kullanılmıştır. 
Kullanılan nicel yöntemler ile araştırmada birçok katılımcıya ulaşmayı ve sonuçların çeşitli geçerlik ve güvenirlik analizlerinden sonra genellenmesini sağlarken, nitel yöntemler ise araştırılan konunun daha derinlemesine incelenmesini sağlamaktadır.

Araştırmanın nicel boyutunda, tarama modeli altında yer alan anket tekniği kullanılmıştır. Veriler, bu çalışma kapsamında Scratch eğitimi alan öğrencilere, uygulama öncesi ve sonrası onların programlamaya karşı tutumlarını ölçen bir ölçek yardımıyla toplanmıştır. Buna ilaveten öğrencilerin programlamaya karşı öz yeterliliklerini belirlemek için uygulama öncesi, öz yeterlilik ölçeği ikinci veri toplama aracı olarak uygulanmıştır.

Araştırmanın nitel boyutunda ise, yarı yapılandırılmış görüşme tekniği kullanılmıştır. Bu veri toplama tekniği nitel araştırmalarda en çok kullanılan tekniklerden biridir (Yıldırım ve Şimşek, 2005). Buna göre, araştırılan konu, bütüncül bir yaklaşımla ele alınır ve yüz yüze görüşülen kişinin ilgili durumu nasıl tecrübe ettiği ve nasıl etkilendiği üzerine derinlemesine durulur. Ayrıca bu teknik araştırmacıya, verilen cevaplar eksik ya da açık değilse ek sorularla deneyimin daha açık ve anlaşılır olması ve çalışmanın amacına göre istenen tüm cevapları alma avantajı sağlamaktadır (Yıldırım ve Şimşek, 2005). Çalışma kapsamında nitel veriler, eğitim öncesi uygulanan öz yeterlilik ölçek puanına göre en düşük 3 en yüksek 3 olmak üzere 6 öğrenci (2 kadın-4 erkek) ile eğitim sonrası birebir görüşme ortamında ses kaydı ile alınmış verilerden oluşmaktadır.

\section{Araştırma Grubu}

Bu araştırmanın verilerini, 2016-2017 öğretim yılında İzmir ili Buca ilçesinde yer alan Dokuz Eylül Üniversitesi BÖTE bölümü 1. sınıf öğrencileri oluşturmaktadır. Örneklem seçiminde, amaçlı örneklem tekniği kullanılmıştır. Balcı (2016)'ya göre, amaçlı örneklem, araştırmacının örneklem seçiminde belli bir kriter belirlediği ve araştırma konusuna ya da amacına göre en uygun olanları seçildiği bir örneklem türüdür. Bu kapsamda, çalışmaya, daha önce lisans ya da önlisans düzeyinde en az bir programlama dersi almış, temel programlama kavramları konusunda yeterli düzeyde bilgi sahibi, 1. sınıfta öğrenim gören ve Dokuz Eylül Üniversitesi BÖTE bölümüne kayıtlı 32 üniversite öğrencisi katılmıştır. Nitel verilerin toplanması için, çalışmaya katılan altı öğrenci belirli kriterlere göre seçilmiştir. Katılımcı özelliklerinin detayları yöntem bölümünde ilgili başlık altında sunulmuştur.

\section{Öğrenme Ortamı}


Araştırma kapsamında, örneklem olarak seçilen 32 öğrenci ile 3 hafta boyunca her hafta sabah iki öğleden sonra iki saat olmak üzere toplam 4 saat süren bir eğitim programı hazırlanmış, ve öğrencilerin bu eğitim programına bağlı olarak Scrath aracına yönelik tutum ve algıları incelenmiştir. Dört haftalık bu programın detayları aşağıdaki tabloda verilmiştir. Bu eğitimin amacı, programlama eğitimini üniversite düzeyinde ilk kez görecek olan BÖTE bölümü 1. sınıf öğretmen adaylarının Scratch programını nasıl tanımladıkları ve bu programa yönelik tutumlarının belirlenmesidir. Toplam üç haftalık program ve haftalık detayları aşağıdaki tabloda verilmiştir.

Tablo 1. Dersin 3-Haftalık Uygulama Süreci

\begin{tabular}{|c|c|c|}
\hline Haftalar & Yapilanlar & İstenenler \\
\hline Ön Görüşme & - $\quad$ Ön görüşme ve anketin uygulanmas1 & \\
\hline 1. Hafta & $\begin{array}{ll}\text { - } & \text { Scratch programının kim tarafindan ne için kullanıldığı } \\
\text { açıklandı } & \\
\text { - } & \text { Scratch programın arayüzü ve özellikleri tanıtıldı } \\
\text { - } & \text { Sahne, kod blokları, karakterler ve program alanı } \\
\text { incelendi. }\end{array}$ & $\begin{array}{l}\text { İlk ders öğrencilerin dersi takip edip, } \\
\text { arayüz tanıtımı ögrenmelerini ve temel } \\
\text { seviyede blokları öğrenmeleri } \\
\text { istenmiştir (Bayrağa tıklayınca } 10 \text { adım } \\
\text { git, } 15 \text { derece dön gibi). }\end{array}$ \\
\hline 2. Hafta & $\begin{array}{l}\text { - Bazı küçük uygulamalar geliştirildi (klavyeden bir tuşa } \\
\text { basılınca kuklanın hareket etmesi, kuklayı koşturup, } \\
\text { kaybedip, oynatma) } \\
\text { Eğitsel bir oyun gösterildi ve bunun Scrath uygulaması } \\
\text { ile nasıl yapıldığı açıklandı. }\end{array}$ & $\begin{array}{l}\text { Bir kuş karakteri oluşturun ve bayrağa } \\
\text { tıklayınca kılık değiştir ve } 50 \text { adım git. }\end{array}$ \\
\hline 3. Hafta & $\begin{array}{l}\text { Eğitsel oyun uygulamalarında temel eylemler } \\
\text { gösterildi ve uygulandı. } \\
\text { - Sahneye yeni karakterler eklendi ve bu karakterlerle } \\
\text { yeni örnekler yapıldı. }\end{array}$ & $\begin{array}{l}\text { Kullanıcı tarafından yön tuşları } \\
\text { kullanılarak küçük bir oyun tasarlaması } \\
\text { istendi. }\end{array}$ \\
\hline 4. Hafta & $\begin{array}{l}\text { - } \quad \text { Anketler yeniden uygulandı. } \\
\text { - } \quad 4 \text { erkek ve } 2 \text { kadın öğrenci ile bire bir görüşme yapıldı. }\end{array}$ & \\
\hline
\end{tabular}

\section{Verilerin Toplanmasl ve Analizi}

Araştırmanın nicel verilerini, 2016-2017 dönemi Mayıs ayında eğitime katılan öğrencilere uygulanan toplam üç bölümden oluşan bir anket oluşturmaktadır. Birinci bölümde katılımcılara ait kişisel verilere dayalı 5 madde bulunmaktadır. Bu maddeler sırasıyla yaş, cinsiyet, mezun olunan lise, daha önce (lisede) programlama eğitimi alınıp alınmadığı hakkında sorular içermektedir. İkinci bölümde ise, öğrencilerin programlamaya ilişkin öz-yeterliliklerini ve tutumları belirlemek için iki ölçek kullanılmıştır. Bu ölçeklerin detayları aşağıdaki gibidir;

\section{Programlamaya İlişkin Öz Yeterlilik Algısı Ölçeği}

Öğrencilerin programlama konusunda öz yeterliliklerini ölçmek için Ramalingam ve Wiedenbeck (1998) tarafından geliştirilen, Altun ve Mazman (2012) tarafından Türkçeye uyarlanan "Programlamaya İlişkin Öz Yeterlilik Algısı Ölçeği” kullanılmıştır. Toplam dokuz 
sorudan oluşturulan ölçek, öğrencilerin programlama konusunda öz yeterliliklerini belirlemektedir. Ölçekte her madde "kendime hiç güvenmiyorum" ile "tamamen güveniyorum" arasında değişmektedir. Ölçeğin Cronbach Alpha güvenirlik katsayısı 0.98 dir.

\section{Bilgisayar Programlama Tutum Ölçeği}

Öğrencilere uygulanan anketin son bölümünde ise katılımcıların programlamaya karşı tutumlarını belirlemek için hem eğitimin başında hem de sonunda uygulanan, Çetin ve Özden (2015) tarafından geliştirilen “Bilgisayar programlama tutum ölçeği” kullanılmıştır. Tablo 2'de detayları verilen ölçek, toplam 18 madde ve 3 boyuttan oluşmaktatır. Her madde beşli Likert tipi ile "hiç katılmıyorum” ile "tamamen katılıyorum” arasında değişmektedir. Ölçeğin iç güvenirlik katsayısı ölçeğin tamamı için 0.90 olarak bulunmuştur.

\section{Tablo 2. Bilgisayar Programlama Tutum Ölçĕ̆i}

\begin{tabular}{lll}
\hline Alt Boyut & Cronbach alpha & Madde Sayısı \\
\hline Duygu/İstek & 0,80 & 6 \\
Biliş & 0,80 & 6 \\
Davranış & 0,90 & 6 \\
Toplam & 0,93 & 18 \\
\hline
\end{tabular}

\section{Verilerin Analizi}

Nicel verilerin analizinde, SPSS 17 programına kodlanmış ve analiz edilmiştir. Ön test ve son test sonuçlarının analizinde bağımlı örneklem t-testi kullanılmış ve anlamlık düzeyi (p) 0.05 olarak benimsenmiştir. Bu test için gerekli varsayımlar arasında yer alan bağımlı ve bağımsız değişkenin analize uygun olması, bağımlı değişkenin gruplar arasında normal dağılım gösterip göstermediği kontrol edilmiş ve hiç bir varsayım ihlal/ihmal edilmemiştir.

Nitel verilerin toplanması için, araştırmacılar tarafından alanyazı araştırmaları ve kullanılan ölçek soruları baz alınarak toplam 4 sorudan ve her soru için çeşitli sonda (detaylandırıcı) sorulardan oluşan bir görüşme formu hazırlanmıştır. Araştırmanın geçerlik ve güvenirlik çalışmaları kapsamında hazırlanan form, uzman görüşüne sunulmuş ve 2 öğrenci ile pilot çalışması yapılmıştır. Görüşme formu son seklini aldıktan sonra, her bir görüşmenin 20 dakikayı geçmemesi planlanmıştır. Her görüşmenin başında katılımcıların demografik bilgileri ve görüşmenin onların onayıyla yapıldığı sözlü olarak kaydedilmiştir. Görüşme esnasında, çalışmanın geçerlik ve 
güvenirliği açısından katılımcıların etkilenmemesi için soruların yönlendirici şekilde sorulmamasına özen gösterilmiştir.

Görüşme sonunda, metne dökülen veriler katılımcılara gönderilip yazılanların birebir onlara ait olduğu, eksiksiz ve yanlış olmadığ 1 doğrulanarak verilerin güvenirliği sağlanmıştır. Görüşme formunda yer alan sorunlar, ek-1 de sunulmuştur.

Nitel verilerin analizinde, içerik analiz yöntemi kullanılmıştır. Bu analiz türünde içerik, belirli kurallara dayalı kodlamalarla ve bu kodlamaların çeşitli temalar altında bir araya getirildiği, özetlendiği, sistematik ve güncellenebilir bir analiz yöntemi olarak tanımlanmaktadır (Büyüköztürk ve diğerleri, 2008). Verilen analizi ve yorumlanması süreci 4 aşamadan oluşmaktadır. Bunlar (1) verilerin kodlanması, (2) kategorilerin oluşturulması, (3) kategorilerin düzenlenmesi ve son olarak (4) bulguların yorumlanması olarak tanımlanabilir. Çalışmadan elde edilen ham veriler, öncelikle kodlara ve araştırmanın amacına bağlı olarak çeşitli temalara ayrılmıştır. $\mathrm{Bu}$ kodlar ve temalar, okuyucu açısından verilerin daha anlamlı bir hale dönüştürülmesini sağladığından, araştırmanın problemine dayalı olarak gereksiz kodların eklenmesini ya da aynı kodların tekrar tekrar kullanılmasını engellemektedir. Nitel verilerin sunulmasında öğrencilerin isimleri verilmeden takma adlar kullanılarak alıntılar yapılmıştır.

\section{Katılımcı Özellikleri}

Katılımcı özellikleri, araştırmanın nitel ve nicel kısmı olmak üzere iki tabloda verilmiştir. Tablo 3'te nitel görüşmelere katılan 6 öğretmen adayının özellikleri yer alırken, Tablo 3-1'de çalışmanın nicel verilerini oluşturan ankete katılan öğretmen adaylarının özellikleri verilmiştir.

Tablo 3. Görüşme Katılımcılarının Özellikleri

f

\begin{tabular}{lr}
\hline Cinsiyet & \\
Kadın & 2 \\
Erkek & 4 \\
Mezun olunan lise türü & \\
Meslek Lisesi & 5 \\
Anadolu Lisesi & 1 \\
Lisede Öğrenilen Programlama Türü &
\end{tabular}




\begin{tabular}{ll} 
Visual Basic & 2 \\
C & 2 \\
C\# & 3 \\
Pascal & 1 \\
\hline
\end{tabular}

Tablo 3 incelendiğinde, görüşemeye katılan öğretmen adaylarının hemen hemen hepsinin meslek lisesi çıkışlı olduğu, bir öğretmen adayı ise Anadolu lisesi mezunu olduğu görülmektedir. Öğrendikleri programlama türleri birbirinden farklı olmasına rağmen, daha çok $\mathrm{C}$ ve türevleri konusunda eğitim aldıkları ve bununla birlikte bütün katılımcıların en az bir dönem olmak üzere programlama dersi ile birlikte algoritma dersi aldıklarını belirtmişlerdir. Anadolu lisesi mezunu olan öğrenci, programlama ve algoritma dersini tamamen kendi kişisel ilgisi sonucu çeşitli videolar ve online derslere katılarak öğrendiğini ifade etmiştir.

Tablo 3-1. Anket katılımcılarının özellikleri

\begin{tabular}{lll}
\hline \multicolumn{1}{l}{ finsiyet } & f & \% \\
\hline Kadın & & \\
Erkek & 11 & 34,4 \\
Yaş & 21 & 65,6 \\
& & \\
$\mathbf{1 8}$ & & \\
$\mathbf{1 9}$ & 2 & 6,6 \\
$\mathbf{2 0}$ & 10 & 31,2 \\
Mezun olunan lise türü & 8 & 25 \\
& & \\
Meslek Lisesi & & \\
Anadolu Lisesi & 26 & 81,2 \\
Düz Lise & 5 & 15,6 \\
Lisede Öğrenilen Programlama Türüi & 1 & 3,1 \\
& & \\
Visual Basic & & \\
C & 5 & 15,6 \\
C\# & 15 & 46,8 \\
Pascal & 13 & 40,6 \\
Java & 1 & 3,1 \\
C++ & 5 & 15,6 \\
& 5 & 15,6 \\
\hline
\end{tabular}

Tablo 3-1'de ise çalışmanın nitel boyutuna katılan öğretmen adaylarının özellikleri incelenmiştir. Katılımcıların \%65,6’sını erkekler oluştururken \%34,4'ünü kadınlar oluşturmaktadır. Öğrenciler mezun oldukları okullar bakımından tamamına yakınının meslek lisesi çıkışlı olduğu ancak Anadolu lisesinden 5, düz liseden 1 öğrenci olmak üzere farklı bölüm mezunlarının da bulunduğu görülmektedir. Öğretmen adaylarının yaş dağılımlarına bakıldığında 
ise çoğunlukla 19, 20 ve $21(\mathrm{n}=10)$ yaşlarında oldukları, ayrıca 18 ile 24 yaşlarında toplam 4 katılımcı da çalışmada yer almıştır. Mezun oldukları lisede öğrenilen programlama dilleri açısından $\mathrm{C}, \mathrm{C} \#$ ve $\mathrm{C}++$ en çok tercih edilen programlama dili olduğu görülmektedir. Bu dillerin diğerlerine göre daha fazla tercih edilmesinin nedeni, görsel programlamada sıklıkla kullanılan Scratch'in programlama aşamasında $\mathrm{C}$ altyapısını kullanmasından kaynaklanabilir.

\section{Bulgular ve Yorum}

$\mathrm{Bu}$ bölümde uygulanan anketten elde edilen sonuçlar ve bu verilere ilişkin tanımlayıcı bulgularla birlikte yarı yapılandırılmış görüşmelerden elde edilen nitel veriler sunulmaktadır.

\section{Öğrencilerin Scratch Eğitiminden Sonra Programlamaya İlişkin Tutumları}

BÖTE bölümü öğrencilerinin programlamaya ilişkin tutumlarını değerlendiren ölçekten elde edilen verilerin ölçek alt boyutlarına göre ön-test ve son-test puan dağılımları aşağıdaki gibidir (Tablo 4). Katılımcılar arasında, ön-test ve son-test arasında ortaya çıkan farkı test etmek için tek örneklem t-test uygulanmıştır. Test sonuçları rapor edilmeden önce test için gerekli varsayımlar kontrol edilmiş ve hiçbir varsayım ihlal edilmemiştir.

Tablo 4. Katılımcıların Programlamaya İlişkin Tutumlarının Ön-Test ve Son-Test Puanlarına Göre Analizi

\begin{tabular}{|c|c|c|c|c|c|c|}
\hline Boyut & Uygulama & $N$ & $\overline{\mathbf{x}}$ & ss & $t$ & $\mathbf{p}$ \\
\hline Duygu/İstek & $\begin{array}{l}\text { Ön-Test } \\
\text { Son-Test }\end{array}$ & $\begin{array}{l}32 \\
32\end{array}$ & $\begin{array}{l}2.90 \\
3.08\end{array}$ & $\begin{array}{l}.74 \\
.86\end{array}$ & .65 & .52 \\
\hline Biliş & $\begin{array}{l}\text { Ön-Test } \\
\text { Son-Test }\end{array}$ & $\begin{array}{l}32 \\
32\end{array}$ & $\begin{array}{l}3.17 \\
3.35\end{array}$ & $\begin{array}{l}.52 \\
.44\end{array}$ & -1.38 & .18 \\
\hline Davranış & $\begin{array}{l}\text { Ön-Test } \\
\text { Son-Test }\end{array}$ & $\begin{array}{l}32 \\
32\end{array}$ & $\begin{array}{l}3.32 \\
3.74\end{array}$ & $\begin{array}{l}.77 \\
.70\end{array}$ & -2.15 & $.04 *$ \\
\hline Ölçek & $\begin{array}{l}\text { Ön-Test } \\
\text { Son-Test }\end{array}$ & $\begin{array}{l}32 \\
32\end{array}$ & $\begin{array}{l}3,12 \\
3,40\end{array}$ & $\begin{array}{l}.64 \\
.68\end{array}$ & $-1,65$ & .10 \\
\hline
\end{tabular}

$\left({ }^{*} \mathrm{p}<0.05\right)$

Tablo 4 incelediğinde, programlamaya karşı tutum ölçeğindeki "Duygu” alt boyutunda, ön test ve son test arasında istatistiksel olarak anlamlı bir farklılık bulunamamıştır. Bunun yanında, öğrencilerin Scratch eğitiminden sonra "Duygu" boyutunda anlamlı bir fark olmasa da daha olumlu tutum sergiledikleri görülmüştür. Benzer şekilde "Biliş̧" alt boyutunda son-test puanları yüksek olmasına rağmen ortaya çıkan sonuç istatistiksel olarak anlamlı bulunamamıştır. "Davranış" alt boyutunda ise, ön-test ve son-test puanları arasında ortaya çıkan fark istatistiksel olarak anlamlıdır 
$(\mathrm{p}<0.05)$. Buna göre, katılımcıların Scratch eğitiminden sonra "Davranış" alt boyutunda programlamaya dönük tutumları olumlu yönde daha da arttığı gözlenmiştir.

Çalışmaya katılan öğrencilerin programlama konusunda öz-yeterliliklerini belirlemek için kullanılan ölçek ve alt boyutlarına ilişkin sonuçlar Tablo 5'te sunulmuştur. Buna göre, katılımcılar "Basit Programlama Görevlerinde” özgüven açısından ortalama bir puan elde ederken, "Karmaşık Görevlerde" oldukça düşük bir özgüven hissettikleri görülmektedir (Tablo 5). Bu durum programlama eğitiminde sıklıkla karşılaşılan bir durumdur. Öğrenciler basit görevleri rahatlıkla yerine getirebilirken, karmaşık görevlerde zorlandıklarını dile getirmişılerdir.

Tablo 5. Programlama Öz-Yeterlilik Ölçek Sonuçları

\begin{tabular}{llllll}
\hline Boyut & n & minimum & maksimum & ortalama & standart sapma \\
\hline Basit Programlama Görevleri & 32 & 1 & 7 & 3.64 & 2.38 \\
Karmaşık Programlama Görevleri & 32 & 1 & 5 & 2.33 & 1.32
\end{tabular}

\section{Öğrencilerin Scratch'e Yönelik Algıları}

Görüşmelerden elde edilen nitel verilere göre, öğrencilerin Scratch konusunda genel tutumları, Scratch programını nasıl tanımladıkları ve Scratch ile programlama konusunda ne düşündüklerine ilişkin bulgular, ilgili temalar altında Tablo 6'da verilmiştir.

Tablo 6. Scratch ile Programlamaya İlişkin Nitel Veri Analiz Sonuçları

\begin{tabular}{|c|c|c|}
\hline Temalar & Kodlar & $\begin{array}{l}\text { n (temalar altında kod } \\
\text { referans sayıları) }\end{array}$ \\
\hline Scratch Nedir & $\begin{array}{l}\text { Motivasyon aracı (2), sanatçı } \\
(2) \text {, program (3), ilk basamak } \\
(5) \text {, oyun (8) }\end{array}$ & ( \\
\hline Nasıl bir program & $\begin{array}{l}\text { Türkçe içerik (2), ücretsiz (3), } \\
\text { birleştir-oynat (4), sürükleyici } \\
\text { (4), görsel (6), kullanışlı (6), } \\
\text { kolay (7), basit (yüksek } \\
\text { öğretim düzeyine uygun } \\
\text { değil) (13), ve eğlenceli (17) }\end{array}$ & 62 \\
\hline Nasıl hissettiriyor & $\begin{array}{l}\text { merak (4), güven (5) ve } \\
\text { mutluluk (5) }\end{array}$ & 14 \\
\hline Gelecekte Kullanırım & $\begin{array}{l}\text { öğrenci talepleri (5), yeni } \\
\text { program (7) ve değişim (11) }\end{array}$ & 23 \\
\hline
\end{tabular}

Yapılan görüşmelerden elde edilen verilerin analizi sonucunda, birinci sınıf öğrencilerinin Scratch ile programlamaya ilişkin algıları dört ana tema üzerinde toplanmıştır. Analizler 
sonucunda, birinci tema "Scratch Nedir" olarak adlandırılmış ve altında 5 kod ortaya çıkmıştır. Kodlar ve her bir kod için görüşmelerde ortaya çıkan referans sayıları, motivasyon aracı (2), sanatçı (2), program (3), ilk basamak (5) ve oyun (8) şeklindedir. Katılımcılara göre, Scratch, programlama eğitiminden önce kullanılması gereken, birçok şeyi kolaylıkla yapabildikleri bir motivasyon kaynağı olan ve oyunlaştıran bir yazılım aracı olarak tanımlamışlardır. Örneğin, bir katılımcı programı şu şekilde tanımlamıştır:

"Bu uygulama [Scratch] dersten önce [programlama I ya da II dersinden önce] ilk olarak gösterilir ise öğrenciler için biraz daha kodlama derslerine ve bilgisayar bölümüne bağlayıcı bir şey olabilir." (öğr1)

Diğer taraftan iki öğrenci Scratch’i bir sanatçı olarak tanımlamışlardır. Onlara göre, Scratch:

"Parçalardan bütün oluşturma yolunda baktığımız zaman bir puzzledan güzel bir tablo ortaya çıkarmaya yardımcı bir sanatçı gibi” (öğr1).

Ayrıca, bir katılımcı Scratch'in "gerçek” programlama dilleri öncesi sadece motivasyon aracı olarak kullanılabileceğini belirtmiştir. Diğer bir katılımcıya göre Scracth programlama dillerinde sıklıkla karşılaşılan kod yazım hatalarının olmadığı, sürükle ve bırak şeklinde çalışan basit ve kullanışlı bir araç olarak ifade etmiştir (öğr2).

İkinci tema, "nasıl bir program” olarak adlandırılmış ve altında 8 kod oluşturulmuştur. Bu kodlar ve referans sayıları sırasıyla; Türkçe içerik (2), ücretsiz (3), birleştir-oynat (4), sürükleyici (4), görsel (6), kullanışlı (6), kolay (7), basit (yüksek öğretim düzeyine uygun değil) (13), ve eğlenceli (17). Çalışmaya katılan 1. sınıf öğretmen adaylarına göre, uygulamanın tamamen görsel olması ve programın geliştirilmesi için sadece sürükle-bırak yöntemi ile yapboz parçaları gibi kolaylıkla yapılabilmesinin, onu oldukça eğlenceli ve kullanışıı yaptığını ifade etmişlerdir. Bir öğretmen adayı görüşlerini şu şekilde ifade etmiştir:

"Yeni başlayan öğrenciler için [programlama öğrenirken] çok eğlenceli olabilir. Özellikle ben evde kardeşimin yanında oturup bu programla ilgili örnekler yaptığım zaman, "abim oyun yapıyor" diyor. Bu benim için çok eğlenceli çünkü [ben bu sayede] programlamanın biraz daha eğlenceli kısmını görmüş oldum." (öğr1)

Bir diğer öğretmen adayı durumu şu şekilde ifade etmiştir:

"Scratch ile ilk oyunu tasarlamak çok heyecan vericiydi. Kodların oluşturulması, oyun tasarımı, programın kullanımı gerçekten çok kolaydı. Bu sayede inanıyorum ki basit bir şekilde eğitsel oyunlar yapabiliriz.” (öğr3)

Başka bir öğretmen adayı bu görüşlere ek olarak, programda en çok ilgi çeken noktanın hem arayüz hem de hata mesajlarının tamamen Türkçe olması olduğunu belirtmişlerdir. Diğer bir 
öğrenci Türkçe dil desteğiyle kullanım kolaylığını "programın kullanımı oldukça kolay bunun yanında Türkçe desteğinin olması benim gibi İngilizce bilmeyen biri olarak oldukça iyi. :)” (öğr2) şeklinde ifade etmiştir. Ancak yine öğretmen adaylarının ikisi, programı üniversite düzeyi açısından basit bulduklarını şu şekilde ifade etmişlerdir: "Program yazacağız diye düşündüm. Daha sonra bu [Scratch] çok daha basit geldi.” (öğr4)

Nitel verilerden formüle edilen üçüncü tema "nasıl hissettiriyor" olarak adlandırılmıştır. Bu tema altında, merak (4), güven (5) ve mutluluk (5) olmak üzere üç kod yer almıştır. Katılımcılara göre, Scratch ile program yazmanın oldukça kolay olması ve oyun yapmak gibi zor ve karmaşık bir sürecin bu program ile rahatça yapılabilmesi kişinin kendine güvenini büyük ölçüde artırdığını belirtmişlerdir. Bir katılımcı bu durumu şöyle ifade etmiştir:

"En azından orada [Scratch programında] yapınca hani nasıl yapıldığını, mantığını kavrayınca oyun konusunda insanın kendine güveni geliyor.”.

Bir diğerine göre ise Scratch kullanımının önceki bilgilerle örtüşmesi öğrenmeyi motive eden bir durum olarak belirtilmiştir:

"C ile Scratch kullanacağımı, daha gelişmiş programlar yapacağımı bilmek benim için çok önemliydi. Çünkü programlama I ve II derslerimizde C göreceğimizi biliyorum. Bu yüzden, bu program ile güzel bir şeyler ortaya çıkabilir bu insanı mutlu ediyor" (öğr5).

Bunun yanında, program ile sonuçları hemen görme imkânı vermesinin katılımcılarda mutluluk duygusunu tetiklediğini belirtmişlerdir. Örneğin bir katılımcı, "bir şeyleri başarmak... yapmak onu yaptığını, nasıl çalıştığını görmek mutluluk veriyor insana.” (öğr1) şeklinde durumu ifade etmiştir.

Bulgulardan elde edilen son tema "gelecekte kullanırım" olarak etiketlenmiştir. Bu tema altında, öğrenci talepleri (5), yeni program (7) ve değişim (11) olmak üzere 3 kod yer almaktadır. buna göre, katılımcılar için Scratch yeni müfredat, öğrenci talepleri, öğrencilerin sahip oldukları imkanlar gibi çeşitli nedenlerle artık bir seçim değil zorunluluk olarak algılanmaktadır. Bir katılımcı durumu şu cümlelerle belirtmiştir: "ben bu programı çok sevdim ve öğrencilerim de çok sever, artık onlar zaten bu programı eminim benden önce duydular. Yeni nesil çok daha önce bu tür şeylerle tanışıyor... yani kısaca bunları öğrenmek bizim için zorunlu." (öğr5). Bir diğer katılımcı ise, Scartch için "belki gelecekte en çok kullanacağım araç olacak çünkü hem kolay ve anlaşılır hem de eğlenceli, bence küçük yaş grupları için oldukça ideal.” (öğr4) olduğunu belirtmiştir.

\section{Sonuç, Tartışma ve Öneriler}


Bu çalışmada, Scratch programı kullanılarak öğretmen adaylarının programlamaya yönelik fikir ve algılarının değişip değişmediğini ölçmek ve programlama eğitimi konusunda bir çözüm önerisi sunmak amaçlanmıştır. Araştırma karma bir yaklaşımla gerçekleştirilmiş, nitel ve nicel verilerden yararlanılmıştır. İlk defa oyun tabanlı görsel programlama dersi gören toplam 32 öğretmen adayından uygulama öncesi programlamaya karşı tutum ve öz yeterlilik ölçekleri uygulanarak nicel veriler toplanmış, 3 haftalık Scratch eğitiminin ardından, belli bir kritere göre seçilen katılımcılarla olgu hakkında daha derinlemesine bilgi toplamak için yüz yüze görüşmeler yapılmıştır. Bu bölümde, verilerin değerlendirilmesi sonucu ortaya çıkan bulgular 1şığında tartışma, öneriler ve sonuç yer almaktadır.

Scratch eğitiminden sonra öğrencilerin programlamaya ilişkin tutumları incelenip, ön-test ve son-test sonuçları karşılaştırıldığında, duygu ve biliş boyutunda anlamlı fark görülmese de sontest puanlarının daha yüksek olduğu ortaya çıkmıştır. Bununla birlikte davranış boyutunda uygulama sonrasında puanlar arasında anlamlı bir fark oluşmuştur. Bu bulgulara göre, Scratch öğrencilerin programlamaya karşı tutumlarında anlamlı pozitif değişiklik gösterdiği söylenebilir. Konuyla ilgili yapılan benzer çalışmalarda da programlamaya Scratch'le başlayan öğrencilerin, ilgi ve tutumlarını olumlu yönde etkilediği görülmüştür (Yüksel ve Gündoğdu, 2018; Cetin, 2016; Genç ve Karakuş, 2011; Saygıner ve Tüzün, 2009). Öğrencilerin programlamaya karşı öz yeterlilikleri ele alındığında ise, öğrencilerin vermiş olduğu cevaplar doğrultusunda, geçmiş programlama deneyimlerini göz önüne alarak, basit kodlama gerektiren görevleri yapabildikleri fakat karmaşık kodlama gerektiren görevleri yapamadıklarını ifade etmişlerdir. Ortaya çıkan bu bulgu sonucunda da, öğrenciler Sratch eğitimi öncesi, kendilerini güven ve güdülenme konusunda eksik hissettikleri söylenebilir. Alanyazında programlama öğretimine ilişkin yapılan çalışmalarda da, derse karşı tutum, programlama dilinin ağır kavramsal yapısı, kodlama dilinin karmaşıklı̆̆ı, kullanılan yöntem ve tekniklerin yetersizliği gibi unsurların ders başarısını etkileyen faktörler arasında olduğu belirtilmiştir (Arslan ve Tanel, 2017; Genç ve Karakuş, 2011; Saygıner ve Tüzün, 2009). Dolayısıyla, karmaşık programlama süreçlerinin öğrencilerin gündelik hayatlarıyla doğrudan ilişkilendirebilecekleri bu tür programlar yardımıyla basitleştirilmesi mümkün olabilir.

$\mathrm{Bu}$ çalışmanın bulgularında yer aldığı gibi, katılımcılar Scratch’i programlaya yeni başlayan öğrenciler için hem üniversite düzeyinde hem de ilköğretimde rahatlıkla kullanılabilecek bir başlangıç aracı olarak gördüklerini belirtmişlerdir. Benzer şekilde Resnick ve diğerlerine (2009) 
göre, bu tür görsel programlama araçları öğrencilerin kod yazma sırasında karşılaşabilecekleri söz dizim hatalarıyla boğuşmadan, yeni başlayanlar için kolay, eğlenceli ve temel olarak programlamanın mantığına odaklanma imkânı sunan başlangıç araçları olarak kullanılabilir. Yine alanyazıdaki birçok çalışmada Scratch'in yaygın bir şekilde kullanılmasının temel gerekçesi olarak basit ve kolay kullanımı olduğu vurgulanmıştır (Kordaki, 2012; Kafai, Fields ve Burke, 2010; Saygıner ve Tüzün, 2009). Ayrıca Scratch benzeri uygulamalarda sunulan kolay çoklu ortam oluşturma özellikleri sayesinde, öğrenciler için Scratch basit oyun geliştirme aracı olarak görüldüğü bu çalışmadan çıkan bir diğer sonuçtur. Resnick ve diğerleri (2010) ve Peppler ve Kafai (2007) tarafından yapılan çalışmalarda bu sonucu desteklemektedir. Buna göre, Scratch benzeri uygulamalar yoluyla kolaylıkla oyun geliştirmek ve müzik, video ve simülasyon destekli uygulamaların kolaylıkla oluşturulması, programlama eğitimde sıklıkla değinilen eksik motivasyon ve ilgi açısından bu uygulamayı bir motivasyon aracına dönüştürmektedir. Uslu (2018) tarafından yapılan bir çalışmada ise Scratch'in ortaokul öğrencilerinin bilgisayar bilimine yönelik farkındalıklarını artırdığı ve yaratıcılıklarını olumlu yönde etkilediği görülmüştür. Bununla birlikte, Scratch ve Alice gibi uygulamalar yoluyla oyun tasarımı geliştirmek, öğrencilerin hem kodlama algoritma mantığını edinmelerine hem de bir ürün geliştirmelerine imkân sağladığı için programlama konusunda ön bilgisi olmayan öğrenciler için kullanılması etkili olabilir.

Çalışmanın bulguları ayrıca görsel programlama dili Scratch'in arayüzü ile sunduğu özellikler bakımından (görsel, kullanışl1, kolay, eğlenceli, basit ve Türkçe dil desteği), öğrencilerin programlamaya karşı tutumlarını olumlu yönde etkilediğini ortaya çıkarmıştır. Genç ve Karakuş (2011) tarafından yapılan çalışma, bu sonuçları destekler niteliktedir. Çalışma sonuçlarına göre; öğrencilerin birçoğu, programı kullanım açısından kolay, basit, eğlenceli ve keyifli bulduğunu, bu yüzden çoğunlukla rahat hissettiklerini ve programı kullanmaktan hoşlandıklarını ortaya koymuştur. Çalışma ayrıca, Scratch gibi görsel programlama araçlarıyla kodlama yapılarının diğer programlama dillerine göre daha rahat öğrenildiği ve anlaşıldığı, ek olarak Scratch’in ileri seviye programlama dillerine geçmeden önce kullanıcıya güven verdiği belirtmiştir. Diğer taraftan bazı öğrenciler, Scratch'in özgün ürün geliştirme ve ileri seviye programlama gibi çeşitlik sınırlılıkları olduğunu ifade etmelerine rağmen, çoklu dil desteği olması ve kodlama için bir söz dizimi (syntax) kullanmaması, Scratch içi önemli bir kullanım kolaylığı sağladığını ifade etmişlerdir. 
Öğrencilerin ayrıca vurguladığı bir diğer konu ise Scratch'in gelecekte onlar için bir zorunluluk olduğudur. Katılımcılar, bu ve benzeri yazılımların onları gelecekteki öğrencileri için gerekli olduğu ve onlar için programlamanın bu şekilde gösterilmesinin daha uygun olacağını belirtmişlerdir. Yükseltürk ve Altıok (2015) tarafından yürütülen çalışmada da, öğretmen adaylarından elde edilen veriler, bu sonucu desteklemektedir. Öğretmen adaylarının gelecekteki öğrenciler için bu tip görsel programlama öğretimine yönelik eğitimlerin artması ve bunun için öncelikle bu programların yaygın şekilde üniversitelerde verilmesi gerektiği görüşü ortaya çıkmıştır (Yükseltürk ve Altıok, 2015). Bununla birlikte Scratch konusunda yapılan çalışmalara bakıldığında, neredeyse araştırmaların \%60 gibi büyük bir çoğunluğu ilk ve orta öğretim düzeyinde yapılmıştır (Çatlak, Tekdal ve Baz, 2015). Bu doğrultuda, Scratch ve benzeri programların hedef grubu ilk ve orta öğretim düzeyi olduğu söylenebilir. Bu nedenle, öğretmen adaylarının ilk ve orta öğretim düzeyinde görsel programlama öğretimi konusunda yeterli alan ve pedagojik bilgi düzeyine erişmeleri oldukça önemlidir.

Sonuç olarak, bu araştırmanın BÖTE'de yürütülmesi ile, Scratch gibi günümüzde oldukça pupüler olan ve hemen hemen her seyiyede kullanılan bir uygulamanın, ilk ve orta öğretim düzeyinde görev alacak Bilişim Teknoloji öğretmen adayları tarafindan tanınması, bu uygulama ile nasıl program geliştirileceğini bilmesi, ve buna yönelik sonuçlarının değerlendirilmesi hedeflenmiştir. Aynı zamanda, BÖTE öğretmen adaylarının müfredatında yer alan programlama derslerinin bu uygulama ile daha eğelenceli ve kolay anlaşılabilecegi, ve derslerine karşı olumsuz tutumlarının değişebileceği öngürülmüştür. Ortaya çıkan sonuçlar 1şığında, ilk ve orta öğretimde sıklıkla kullanılan Scratch ve benzeri programların, yüksek öğretim lisans programlarına programlamanın pedeogjik yaklaşımları olarak dahil edilmesi önerilmektdir. Bu çalışma sonucunda bu uygulamaların, her ne kadar eğleneceli, görsel, kolay ve yaratıcı olduğu vurgulansa da üniversite düzeyinde programlama öğretimi için "basit” görüldüğü sonucu dikkate alınmalı ve farklı bir ders içeriğine entegre edilerek gösterilmesi önerilmektedir. Diğer taraftan, Scratch gibi uygulamalarla programlama öğretiminin bir oyun gibi düşünülmesi ve bazı gündelik hayatta karşılaşabilecek örneklerin kolaylıkla çözülebilmesi, bu uygulamanın BÖTE yüksek öğretim müfretadına yeni giren Algoritma dersinin bir parçası yapabilir ve algoritma ile ilgili bazı kavramların daha kolay anlaşılmasını ve yürütülmesini sağlayabilir. 


\section{Kaynakça}

Akpınar, Y. \& Altun, Y. (2014). Bilgi toplumu okullarında programlama eğitimi gereksinimi. İlkögretim Online, 13(1), 1- 4.

Allan, V. \& Kolesar, M. V. (1997). Teaching computer science: a problem solving approach that works. SigCUE Outlook, 25(1-2), 2-10.

Altun, A., \& Mazman, S. G. (2012). Programlamaya ilişkin Öz Yeterlilik Algısı Ölçeğinin Türkçe Formunun Güvenirlik ve Geçerlik Çalışması. Eğitimde ve Psikolojide Ölçme ve Değerlendirme Dergisi, 3(2), 297-308.

Ananiadou, K., \& Claro, M. (2009). 21st century skills and competences for new millennium learners in OECD countries.

Arslan, K. \& Tanel Z. (2017). Arduino ile dinleyen öğrencilerden yapan öğrencilere geçiş. In 11th International Computer \& Instructional Technologies Symposium (ICITS), Malatya, Turkey, 664-674.

Atmatzidou, S. \& Demetriadis, S. (2016). Advancing students' computational thinking skills through educational robotics: A study on age and gender relevant differences. Robotics and Autonomous Systems, 75, 661-670.

Büyüköztürk, Ş., Çakmak, E. K., Akgün, Ö. E., Karadeniz, Ş., \& Demirel, F. (2017). Bilimsel araştırma yöntemleri. Pegem Atıf Indeksi, 1-360.

Çatlak, Ş., Tekdal, M. \& Baz, F. Ç. (2015). Scratch yazılımı ile programlama öğretiminin durumu: Bir doküman inceleme çalışması. Journal of Instructional Technologies \& Teacher Education, 4(3).

Cetin, I. \& Ozden, M. Y. (2015). Development of computer programming attitudescale for university students. Computer Applications in Engineering Education, 23 (5), 667672.

Cetin, I. (2016). Preservice Teachers' Introduction to Computing: Exploring Utilization of Scratch. Journal of Educational Computing Research, 54(7), 997-1021.

Clements, D. H. \& Gullo, D. F. (1984). Effects of computer programming on young children's cognition. Journal of Educational psychology, 76(6), 1051.

Davidson, K., Larzon, L., \& Ljunggren, K. (2010). Self-efficacy in programming among STS students. Retrieved August, 12, 2013. 
Programlama Eğitiminde Scratch'in Kullanılması: Öğretmen Adaylarının Tutum ve Algıları

Fessakis, G., Gouli, E. \& Mavrodi, E. (2013). Problem solving by 5-6 years old kindergarten children in a computer programming environment: A case study. Computers and Education 63, 87- 97.

Genç, Z. \& Karakuş, S. (2011). Tasarımla öğrenme: eğitsel bilgisayar oyunları tasarımında scratch kullanımı. In 5th International Computer \& Instructional Technologies Symposium (ICITS)

Green, J. C., Krayder, H. \& Mayer, E. (2005). Combining qualitative and quantitative methods in social inquiry. In B. Somekh \& C. Lewin (Eds.). Research methods in the social sciences (pp. 275-282). London: Sag

Günüç, S., Odabaşı, H.F. \& Kuzu, A. (2013). 21. Yüzyıl öğrenci özelliklerinin öğretmen adayları tarafından tanımlanması: Bir Twitter uygulaması, Eğitimde Kuram ve Uygulama, 9(4), 436455.

Ismail, M. N., Ngah, N. A., \& Umar, I. N. (2010). Instructional strategy in the teaching of computer programming: a need assessment analyses. TOJET: The Turkish Online Journal of Educational Technology, 9(2).

Jenkins, T. (2002). On the difficulty of learning to program. In Proceedings of the 3rd Annual Conference of the LTSN Centre for Information and Computer Sciences, 4(2), 53-58.

Kafai, Y. B., Fields, D. A., \& Burke, W. Q. (2010). Entering the clubhouse: Case studies of young programmers joining the online Scratch communities. Journal of Organizational and End User Computing (JOEUC), 22(2), 21-35.

Karabak, D. \& Güneş, A., Ortaokul birinci sınıf öğrencileri için yazılım geliştirme alanında müfredat önerisi." Journal of Research in Education and Teaching, 2(3), 175-181 (2013).

Kobsiripat, W. (2015). Effects of the media to promote the scratch programming capabilities creativity of elementary school students. Procedia-Social and Behavioral Sciences, 174, 227-232.

Kordaki, M. (2012). Diverse categories of programming learning activities could be performed within Scratch. Procedia-Social and Behavioral Sciences, 46, 1162-1166.

Maloney, J. H., Peppler, K., Kafai, Y., Resnick, M., \& Rusk, N. (2008). Programming by choice: urban youth learning programming with scratch. Communications of the ACM, 40(1), 367371. 
Maloney, J., Burd, L., Kafai, Y., Rusk, N., Silverman, B., \& Resnick, M. (2004). Scratch: a sneak preview [education]. In Proceedings. Second International Conference on Creating, Connecting and Collaborating through Computing, 104-109.

Mazman, S. G., \& Altun, A. (2013). Programlama-I dersinin BÖTE bölümü öğrencilerinin programlamaya ilişkin öz yeterlilik algıları üzerine etkisi. Journal of Instructional Technologies \& Teacher Education, 2(3), 24-29.

Peppler, K. A., \& Kafai, Y. B. (2007). From SuperGoo to Scratch: Exploring creative digital media production in informal learning. Learning, media and technology, 32(2), 149-166.

Resnick, M., Kafai, Y., Maloney, J., Rusk, N., Burd, L. \& Silverman, B. (2003). A Networked, Media-Rich Programming Environment to Enhance Technological Fluency at After-School Centers in Economically-Disadvantaged Communities. Proposal to National Science Foundation.

Resnick, M., Maloney, J., Monroy-Hernández, A., Rusk, N., Eastmond, E., Brennan, K., ... \& Kafai, Y. B. (2009). Scratch: Programming for all. Commun. Acm, 52(11), 60-67.

Robins, A., Rountree, J. \& Rountree, N. (2003). Learning and teaching programming: A review and discussion. Computer science education, 13(2), 137-172.

Rubio, M. A., Hierro, C. M., \& Pablo, A. P. D. M. (2013). Using arduino to enhance computer programming courses in science and engineering. In Proceedings of EDULEARN13 conference, 1-3.

Saygıner, Ş. \& Tüzün, H. (2009). Programlama eğitiminde yaşanan zorluklar ve çözüm önerileri. In 11th International Computer \& Instructional Technologies Symposium (ICITS), Malatya, Turkey (pp. 78-90).

Taylor, M., Harlow, A. \& Forret, M. (2010). Using a computer programming environment and an interactive whiteboard to investigate some mathematical thinking. Procedia-Social and Behavioral Sciences, 8, 561-570.

Uslu, N. A. (2018). Görsel Programlama Etkinliklerinin Ortaokul Öğrencilerinin Bilgi-I̧şlemsel Düşünme Becerilerine Etkisi. Ege Eğitim Teknolojileri Dergisi, 2(1), 19-31.

Verma, G. K. \& Mallick, K. (2005). Researching education: Perspectives and techniques. London: Falmer Press.

Yıldırım, A. \& Şimşek, H. (2005). Sosyal bilimlerde nitel araştırma yöntemleri Ankara: Seçkin Yayıncılık. 
Programlama Eğitiminde Scratch'in Kullanılması: Öğretmen Adaylarının Tutum ve Algıları

Yüksel, S., \& Gündoğdu, K. (2018). Scratch Öğretiminde Ayrılıp Birleşme Tekniği Kullanımının Derse Yönelik Tutuma Akademik Başarıya ve Kalıcılığa Etkisi. Ege Eğitim Dergisi, 19(1), 245-261.

Yükseltürk, E. \& Altık, S. (2015). Bilişim teknolojileri öğretmen adaylarının bilgisayar programlama öğretimine yönelik görüşleri. Amasya Üniversitesi Eğitim Fakültesi Dergisi, $4(1), 50-65$. 